\title{
Evaluation of interferon-induced transmembrane protein-3 (IFITM3) rs7478728 and rs3888188 polymorphisms and the risk of pulmonary tuberculosis
}

\author{
MOHAMMAD NADERI ${ }^{1}$, MOHAMMAD HASHEMI $^{2}$, FATEMEH ABEDIPOUR $^{1}$, \\ GHOLAMREZA BAHARI $^{2}$, MARYAM REZAEI ${ }^{2}$ and MOHSEN TAHERI ${ }^{3}$ \\ ${ }^{1}$ Infectious Diseases and Tropical Medicine Research Center; ${ }^{2}$ Department of Clinical Biochemistry, School of Medicine; \\ ${ }^{3}$ Genetic of Non-Communicable Disease Research Center, Zahedan University of Medical Sciences, Zahedan 98167, Iran
}

Received June 3, 2016; Accepted September 21, 2016

DOI: $10.3892 /$ br.2016.763

\begin{abstract}
The current study aimed to examine the possible association between the interferon-induced transmembrane protein-3 (IFITM3) gene polymorphisms and risk of pulmonary tuberculosis (PTB) in a sample population. This case-control study was conducted on 188 PTB patients and 169 healthy subjects. The rs7478728 and rs3888188 variants of IFITM3 were genotyped using polymerase chain reaction-restriction fragment length polymorphism. The findings showed no significant association between rs7478728 polymorphism and risk of PTB. Regarding rs3888188 polymorphism, the TG genotype as well as $G$ allele significantly increased the risk of PTB [odds ratio $(\mathrm{OR})=2.48,95 \%$ confidence interval (CI): 1.42-4.53; $\mathrm{P}=0.002$, and $\mathrm{OR}=2.26,95 \% \mathrm{CI}: 1.33-3.86$; $\mathrm{P}=0.003$, respectively]. In conclusion, the findings revealed that rs3888188 polymorphism increased the risk of PTB in a sample of Iranian population. Additional investigation with larger sample sizes and different ethnicities are needed to verify our findings.
\end{abstract}

\section{Introduction}

Tuberculosis (TB), caused by Mycobacterium tuberculosis (MTB) infection, is a public health problem globally $(1,2)$. According to the WHO report on the worldwide control of TB, approximately 8.6 million new cases occurred in 2012 (3). Although almost $33 \%$ of the population is infected with TB, only $5-10 \%$ of infected cases develop active TB (3), which suggests a major role of genetic factors in host immunity.

Interferon- $\gamma($ IFN $\gamma)$ is produced and released by host cells in response to the presence of numerous pathogens (4). It plays a key role in macrophage activation during MTB infection (5).

Correspondence to: Professor Mohammad Hashemi, Department of Clinical Biochemistry, School of Medicine, Zahedan University of Medical Sciences, Khalij Fars Boulevard, Zahedan 98167, Iran E-mail:mhd.hashemi@gmail.com; hashemim@zaums.ac.ir

Key words: tuberculosis, IFITM3, polymorphism
Individuals defective in the genes for $I F N \gamma$ or $I F N \gamma$ receptor $(I F N \gamma R)$ have been indicated to be susceptible for mycobacterial infections including MTB (6). Previously, we showed an association between $I F N \gamma$ and $I F N \gamma R$ variants and risk of pulmonary TB (PTB) $(7,8)$.

Interferon-induced transmembrane protein-3 (IFITM3) is a double transmembrane protein that can be upregulated by IFNs and participates in INF-triggered processes, such as homotypic cell adhesion, anti-proliferative activities in tumor pathogenesis, and the innate immune response to virus infections (9-13). The IFITM3 gene is mapped to an IFITM gene cluster on chromosome 11p15.5 (14). In a genome wide scan, Stein et al (15) identified that one of the TB-linked loci was located in this chromosome region. To the best of our knowledge, there is only one report regarding the impact of IFITM gene polymorphisms on the risk of TB (16). Therefore, the present study aimed to examine the possible associations between polymorphisms of IFITM3 gene and susceptibility to PTB in a sample of Iranian population.

\section{Materials and methods}

Patients. This case-control study was performed on 188 PTB patients and 169 age- and gender-matched healthy individuals. The enrollment process and study design are described elsewhere (17-23). Briefly, the cases were chosen from PTB patients admitted to a University-Affiliated Hospital (Bou-Ali Hospital, Zahedan, Iran, referral center for TB) with no clinical symptoms or family history of TB. TB was diagnosed by clinical symptoms, posterior-anterior chest radiography, presence of acid-fast-bacilli on a sputum smear, and culturing MTB organisms from a specimen taken from the patient and response to therapy, as described previously (20-23). The project was approved by the local Ethics Committee of the Zahedan University of Medical Sciences and informed consent was obtained from all subjects. DNA was extracted from whole blood samples using the salting out method (24).

Genotyping. Genotyping of IFTIM3 rs7478728 and rs3888188 polymorphisms was performed using the polymerase chain reaction (PCR)-restriction fragment length polymorphism 
Table I. Primer sequences used for the detection of IFITM3 gene polymorphisms.

\begin{tabular}{|c|c|c|c|c|}
\hline Polymorphisms & $\begin{array}{l}\text { Sequence } \\
\left(5^{\prime} \rightarrow 3^{\prime}\right)\end{array}$ & $\begin{array}{l}\text { Restriction } \\
\text { enzyme }\end{array}$ & $\begin{array}{l}\text { Product } \\
\text { size (bp) }\end{array}$ & $\begin{array}{c}\text { Anneling } \\
\text { temperature }\left({ }^{\circ} \mathrm{C}\right)\end{array}$ \\
\hline rs7478728 C>T & $\begin{array}{l}\text { F: TTAGCCCTCAGCCCCTCTTTCGTC } \\
\text { R: CTGTTGACAGGAGAGAAGAAGGTT }\end{array}$ & $A l w 26 \mathrm{I}$ & $\begin{array}{l}\text { T allele: } 217,29 \\
\text { C allele: } 246\end{array}$ & 53 \\
\hline $\mathrm{rs} 3888188 \mathrm{~T}>\mathrm{G}$ & $\begin{array}{l}\text { F: CACAGTGAGGGTTATGGGAGAC } \\
\text { R: ACTGTTGACAGGAGAGAAGAAGGTT }\end{array}$ & Нру188I & $\begin{array}{l}\text { G allele: } 340,246 \\
\text { T allele: } 586\end{array}$ & 54 \\
\hline
\end{tabular}

F, forward; R, reverse; IFITM3, interferon-induced transmembrane protein-3.

method. The primer sequences are shown in Table I. In each $0.20 \mathrm{ml}$ PCR reaction tube, $1 \mu \mathrm{l}$ of genomic DNA $(\sim 100 \mathrm{ng} / \mathrm{ml})$, $1 \mu \mathrm{l}$ of each primer $(10 \mu \mathrm{M}), 10 \mu \mathrm{l}$ of $2 \mathrm{X}$ Prime Taq Premix

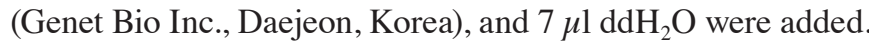

Amplification was carried out with an initial denaturation step of $5 \mathrm{~min}$ at $95^{\circ} \mathrm{C}$ followed by 30 cycles of $30 \mathrm{sec}$ at $95^{\circ} \mathrm{C}$, annealing at $53^{\circ} \mathrm{C}$ for $\mathrm{rs} 7478728$ and $54^{\circ} \mathrm{C}$ for rs 3888188 for $30 \mathrm{sec}$ and extension at $72^{\circ} \mathrm{C}$ for $30 \mathrm{sec}$. Final extension was performed at $72^{\circ} \mathrm{C}$ for $5 \mathrm{~min}$.

For rs7478728, $10 \mu \mathrm{l}$ of PCR products was digested with Alw26I restriction enzyme (Fermentas, Glen Burnie, MD, USA) and then separated by electrophoresis in $2 \%$ agarose gels. The $\mathrm{C}$ allele was undigested (246-bp), while the $\mathrm{T}$ allele was digested and produced 217- and 29-bp fragments (Fig. 1).

For the rs 3888188 variant, the PCR products were digested with Hpy188I restriction enzyme (Fermentas). The T allele was undigested (586-bp), while the $\mathrm{G}$ allele digested and produced 340- and 246-bp fragments (Fig. 2).

To confirm the genotyping quality for each polymorphism, $\sim 20 \%$ of random samples were regenotyped and the findings confirmed the preceding genotyping results.

Statistical analysis. Statistical analysis of the data was performed using the SPSS 20.0 software (IBM SPSS, Armonk, NY, USA). The analysis was performed by the $\chi^{2}$ test or independent sample t-test according to the data. The associations between genotypes and PTB were calculated by computing the odds ratio (OR) and $95 \%$ confidence interval (CI) from logistic regression analyses. The Hardy-Weinberg equilibrium (HWE) for cases and controls was calculated by $\chi^{2}$ test. $\mathrm{P}<0.05$ was considered to indicate a statistically significant difference.

\section{Results}

Patient characteristics. A total of 357 subjects including 188 confirmed PTB patients (73 males, 115 females; ages $50.0 \pm 19.5$ years) and 169 unrelated healthy subjects ( 75 males, 94 females; ages $47.9 \pm 15.0$ years) were assessed. There was no statistically significant difference among the groups regarding gender and age $(\mathrm{P}>0.05)$.

Association between the polymorphisms and PTB risk. Genotypes and allele frequencies of the IFITM3 polymorphisms are shown in Table II. Regarding rs 7478728 polymorphism, the findings indicated that this variant was not associated with the risk of $\mathrm{PTB}$ in codominant $(\mathrm{OR}=1.32,95 \% \mathrm{CI}$ : 0.80-2.17,

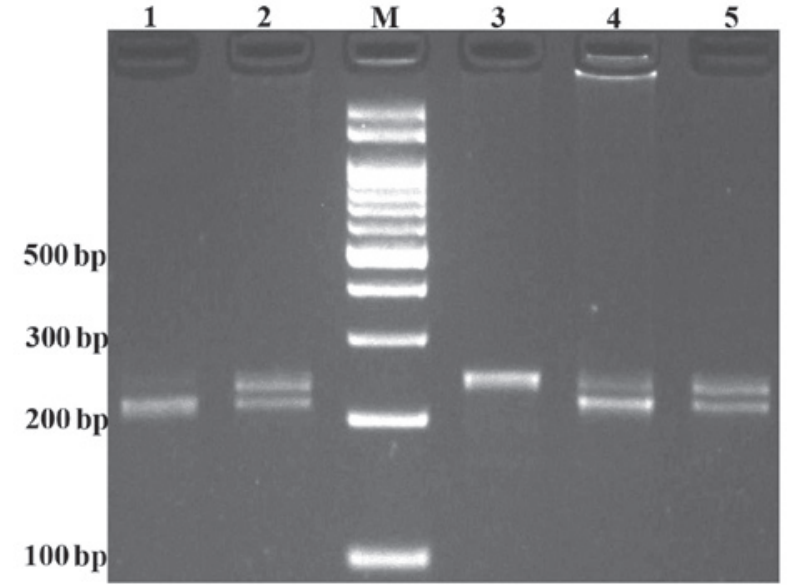

Figure 1. IFITM3 rs7478728 C>T polymorphism using polymerase chain reaction-restriction fragment length polymorphism methods. The $\mathrm{C}$ allele was undigested (246-bp), while the T allele was digested by the Alw26I restriction enzyme, and 217- and 29-bp fragments were produced. M, DNA marker; lane 1, TT; lanes 2, 4 and 5, CT; and lane 3, CC.

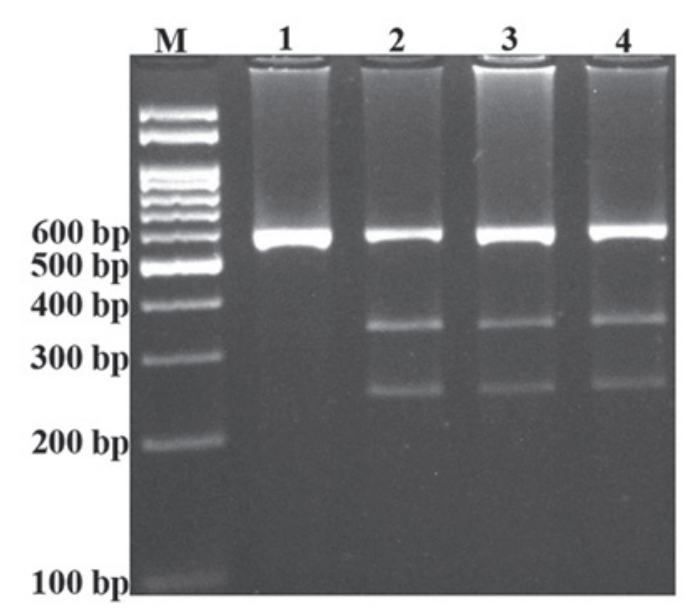

Figure 2. IFITM3 rs3888188 T>G polymorphism using polymerase chain reaction-restriction fragment length polymorphism methods. The $\mathrm{T}$ allele was undigested (586-bp), while the $\mathrm{G}$ allele was digested by the Hpy188I restriction enzyme and produces 340 - and 246-bp fragments. M, DNA marker; lane 1, TT; and lanes 2-4, TG.

$\mathrm{P}=0.337, \mathrm{CT}$ vs. $\mathrm{CC} ; \mathrm{OR}=2.04,95 \% \mathrm{CI}: 0.63-6.61, \mathrm{P}=0.362$, TT vs. CC), dominant (OR=1.35, 95\% CI: 0.82-2.21, $\mathrm{P}=0.293$, $\mathrm{CT}+\mathrm{TT}$ vs. $\mathrm{CC})$, and recessive $(\mathrm{OR}=1.65,95 \% \mathrm{CI}: 0.54-5.02$, $\mathrm{P}=0.538 \mathrm{TT}$ vs. $\mathrm{CC}+\mathrm{CT}$ ) inheritance model tested. The T allele 
Table II. Frequency distribution of IFITM3 rs7478728 and rs3888188 gene polymorphisms in PTB and controls.

\begin{tabular}{|c|c|c|c|c|}
\hline Polymorphisms & Case n $(\%)$ & Control n (\%) & OR $(95 \% \mathrm{CI})$ & P-value \\
\hline \multicolumn{5}{|l|}{ rs7478728 C>T } \\
\hline \multicolumn{5}{|l|}{ Codominant } \\
\hline $\mathrm{CC}$ & $38(20.2)$ & $43(25.4)$ & 1.00 & - \\
\hline $\mathrm{CT}$ & $141(75.0)$ & $121(71.6)$ & $1.32(0.80-2.17)$ & 0.337 \\
\hline $\mathrm{TT}$ & $9(4.8)$ & $5(3.0)$ & $2.04(0.63-6.61)$ & 0.362 \\
\hline \multicolumn{5}{|l|}{ Dominant } \\
\hline $\mathrm{CC}$ & $38(20.2)$ & $43(25.4)$ & 1.00 & - \\
\hline $\mathrm{CT}+\mathrm{TT}$ & $150(79.8)$ & $126(74.6)$ & $1.35(0.82-2.21)$ & 0.293 \\
\hline \multicolumn{5}{|l|}{ Recessive } \\
\hline $\mathrm{CC}+\mathrm{CT}$ & $179(95 . .2)$ & $164(97.0)$ & 1.00 & \\
\hline $\mathrm{TT}$ & $9(4.8)$ & $5(3.0)$ & $1.65(0.54-5.02)$ & 0.538 \\
\hline \multicolumn{5}{|l|}{ Allele } \\
\hline $\mathrm{C}$ & 217 (57.7) & $207(61.2)$ & 1.00 & - \\
\hline $\mathrm{T}$ & $159(42.3)$ & $131(38.8)$ & $1.16(0.86-1.56)$ & 0.377 \\
\hline \multicolumn{5}{|l|}{ rs3888188 T>G } \\
\hline $\mathrm{TT}$ & 139 (73.9) & 148 (87.6) & 1.00 & - \\
\hline $\mathrm{TG}$ & $49(26.1)$ & $21(12.4)$ & $2.48(1.42-4.35)$ & 0.002 \\
\hline GG & $0(0.0)$ & $0(0.0)$ & - & - \\
\hline \multicolumn{5}{|l|}{ Allele } \\
\hline $\mathrm{T}$ & 327 (87.0) & $317(93.8)$ & 1.00 & - \\
\hline $\mathrm{G}$ & $49(13.0)$ & $21(6.2)$ & $2.26(1.33-3.86)$ & 0.003 \\
\hline
\end{tabular}

IFITM3, interferon-induced transmembrane protein-3; PTB, pulmonary tuberculosis; OR, odds ratio; CI, confidence interval.

Table III. Interaction of IFITM3 rs7478728 and rs3888188 gene polymorphisms on PTB risk.

\begin{tabular}{|c|c|c|c|c|c|}
\hline rs7478728 C>T & $\mathrm{rs} 3888188 \mathrm{~T}>\mathrm{G}$ & Case n $(\%)$ & Control n (\%) & OR $(95 \% \mathrm{CI})$ & P-value \\
\hline $\mathrm{CC}$ & TT & $29(15.4)$ & $39(23.1)$ & 1.00 & - \\
\hline $\mathrm{CT}$ & TT & $104(55.3)$ & $104(61.5)$ & $1.34(0.77-2.34)$ & 0.329 \\
\hline $\mathrm{CT}$ & $\mathrm{TG}$ & 37 (19.7) & $17(10.1)$ & 2.93 (1.38-6.19) & 0.006 \\
\hline TT & $\mathrm{TT}$ & $6(3.2)$ & $5(3.0)$ & $1.61(0.45-5.81)$ & 0.524 \\
\hline $\mathrm{CC}$ & $\mathrm{TG}$ & $9(4.8)$ & $4(2.4)$ & $3.03(0.85-10.80)$ & 0.128 \\
\hline $\mathrm{TT}$ & $\mathrm{TG}$ & $3(1.6)$ & $0(0.0)$ & - & - \\
\hline
\end{tabular}

IFITM3, interferon-induced transmembrane protein-3; PTB, pulmonary tuberculosis; OR, odds ratio; CI, confidence interval.

was not associated with the risk of PTB $(\mathrm{OR}=1.16,95 \% \mathrm{CI}$ : 0.86-1.56, $\mathrm{P}=0.377$ ) compared to $\mathrm{C}$ allele.

Regarding the rs3888188 variant, the results revealed that TG genotype significantly increased the risk of PTB compared to TT genotype $(\mathrm{OR}=2.48,95 \% \mathrm{CI}$ : $1.42-4.35$; $\mathrm{P}=0.002)$. Similarly, the $\mathrm{G}$ allele increased the risk of PTB in comparison with $\mathrm{T}$ allele $(\mathrm{OR}=2.26,95 \% \mathrm{CI}$ : $1.33-3.86$; $\mathrm{P}=0.003)$.

The interaction of the two variants of the IFITM3 gene was analyzed (Table III) and the findings suggested that the $\mathrm{CT} / \mathrm{TG}$ genotype significantly increased the risk of PTB compared to $\mathrm{CC} / \mathrm{TT}$ genotype $(\mathrm{P}=0.006)$.
The genotype of IFITM3 rs7478728 variant in cases and controls was not in HWE $\left(\chi^{2}=54.1, \mathrm{P}<0.001\right.$ and $\chi^{2}=43.64$, $\mathrm{P}<0.001$, respectively). Regarding the IFITM3 rs3888188 variant, the genotype in controls $\left(\chi^{2}=0.74, \mathrm{P}=0.389\right)$ but not in cases $\left(\chi^{2}=4.22, \mathrm{P}=0.040\right)$ was in HWE.

\section{Discussion}

In the present study, we examined the possible association between IFITM3 rs7478728 and rs3888188 polymorphisms and the risk of PTB in a sample of Iranian population. Our findings did not support an association between rs7478728 
variant and risk of PTB in the population studied. However, we found that TG genotype as well as $\mathrm{G}$ allele of rs3888188 polymorphism significantly increased the risk of PTB. There is only one study concerning the possible association between IFITM3 variants and risk of TB (16). Shen et al (16) have found that the $\mathrm{rs} 3888188 \mathrm{G}$ allele increased the risk of pediatric $\mathrm{TB}(\mathrm{OR}=1.30,95 \% \mathrm{CI}: 1.08-1.56$; $\mathrm{P}=0.039)$. In addition, they found that the rs7478728 $\mathrm{T}$ allele was significantly associated with pediatric TB $(\mathrm{OR}=1.34,95 \% \mathrm{CI}$ : 1.07-1.68; $\mathrm{P}=0.010)$, but not after Bonferroni correction $(\mathrm{P}=0.082)$. Authors of that study also evaluated the effect of rs3888188 (-204 T>G) variant on IFITM3 transcription in vitro and found that the promoter activity of rs3888188 $\mathrm{G}$ allele was lower than that of the T allele. Similarly, peripheral-blood mononuclear cells carrying the rs3888188 GG genotype showed a reduced IFITM3 mRNA level compared to cells carrying TT or GT genotype. It was concluded that the rs3888188 variant is a functional promoter polymorphism of IFITM3 that increased the risk of pediatric TB in the Han Chinese population (16). IFITM3 has been recognized as a key component of the IFN $\gamma$ signaling pathway and downregulation of IFITM3 via siRNA significantly reduced the antiviral activities of IFN $\gamma$ by $40-70 \%(12,13)$. It is thus a potential candidate gene for TB susceptibility.

IFITM proteins are key mediators of the host antiviral response $(11-13,25,26)$. Everitt et al $(25)$ showed that mice lacking IFITM3 gene display fulminant viral pneumonia following infection with a low-pathogenicity influenza virus. Similarly, in an in vitro study, an increase in viral replication was observed in the absence of IFITM3, and re-introduction of IFITM3 limited the replication of the influenza A virus (25).

One of the limitations of the present study is the relatively small sample sizes. There is no clear explanation for deviation from HWE for the IFITM3 rs7478728 variant in our population. The probable reason may be due to genetic drift.

In conclusion, our findings suggest that IFITM3 rs3888188 polymorphism significantly increased the risk of PTB in a sample of Iranian population. Additional studies with larger sample sizes and diverse ethnicities are necessary to confirm these findings.

\section{Acknowledgements}

The present study was funded by a dissertation research grant (M.D. thesis of FA no. 7265) from the Zahedan University of Medical Sciences. The authors would like to thank the patients and healthy subjects who willingly participated in the study.

\section{References}

1. Lin PL and Flynn JL: Understanding latent tuberculosis: A moving target. J Immunol 185: 15-22, 2010.

2. Oxlade O, Schwartzman K, Behr MA, Benedetti A, Pai M, Heymann J and Menzies D: Global tuberculosis trends: A reflection of changes in tuberculosis control or in population health? Int J Tuberc Lung Dis 13: 1238-1246, 2009.

3. Zumla A, George A, Sharma V, Herbert N and Baroness Masham of Ilton: WHO's 2013 global report on tuberculosis: Successes, threats, and opportunities. Lancet 382: 1765-1767, 2013.
4. Stark GR: How cells respond to interferons revisited: From early history to current complexity. Cytokine Growth Factor Rev 18: 419-423, 2007.

5. Lee $\mathbf{J}$ and Kornfeld $\mathrm{H}$ : Interferon- $\gamma$ regulates the death of M. tuberculosis-infected macrophages. J Cell Death 3: 1-11, 2010.

6. Ottenhoff TH, Kumararatne D and Casanova JL: Novel human immunodeficiencies reveal the essential role of type-I cytokines in immunity to intracellular bacteria. Immunol Today 19: 491-494, 1998.

7. Naderi M, Hashemi M, Rezaei M and Safdari A: Association of genetic polymorphisms of IFNGR1 with the risk of pulmonary tuberculosis in Zahedan, Southeast Iran. Tuberc Res Treat 2015: 292505, 2015.

8. Hashemi M, Sharifi-Mood B, Nezamdoost M, Moazeni-Roodi A Naderi M, Kouhpayeh H, Taheri M and Ghavami S: Functional polymorphism of interferon- $\gamma($ IFN- $\gamma)$ gene +874 T/A polymorphism is associated with pulmonary tuberculosis in Zahedan, Southeast Iran. Prague Med Rep 112: 38-43, 2011.

9. Seyfried NT, Huysentruyt LC, Atwood JA III, Xia Q, Seyfried TN and Orlando R: Up-regulation of NG2 proteoglycan and interferon-induced transmembrane proteins 1 and 3 in mouse astrocytoma: A membrane proteomics approach. Cancer Lett 263: 243-252, 2008.

10. Fan J, Peng Z, Zhou C, Qiu G, Tang H, Sun Y, Wang X, Li Q, Le $\mathrm{X}$ and Xie K: Gene-expression profiling in Chinese patients with colon cancer by coupling experimental and bioinformatic genomewide gene-expression analyses: Identification and validation of IFITM3 as a biomarker of early colon carcinogenesis. Cancer 113: 266-275, 2008.

11. Brass AL, Huang IC, Benita Y, John SP, Krishnan MN, Feeley EM, Ryan BJ, Weyer JL, van der Weyden L, Fikrig E, et al: The IFITM proteins mediate cellular resistance to influenza A H1N1 virus, West Nile virus, and dengue virus. Cell 139: 1243-1254, 2009.

12. Jiang D, Weidner JM, Qing M, Pan XB, Guo H, Xu C, Zhang X, Birk A, Chang J, Shi PY, et al: Identification of five interferon-induced cellular proteins that inhibit west nile virus and dengue virus infections. J Virol 84: 8332-8341, 2010.

13. Weidner JM, Jiang D, Pan XB, Chang J, Block TM and Guo JT: Interferon-induced cell membrane proteins, IFITM3 and tetherin, inhibit vesicular stomatitis virus infection via distinct mechanisms. J Virol 84: 12646-12657, 2010.

14. Lange UC, Saitou M, Western PS, Barton SC and Surani MA: The fragilis interferon-inducible gene family of transmembrane proteins is associated with germ cell specification in mice. BMC Dev Biol 3: 1, 2003.

15. Stein CM, Zalwango S, Malone LL, Won S, Mayanja-Kizza H, Mugerwa RD, Leontiev DV, Thompson CL, Cartier KC, Elston RC, et al: Genome scan of M. tuberculosis infection and disease in Ugandans. PLoS One 3: e4094, 2008.

16. Shen C, Wu XR, Jiao WW, Sun L, Feng WX, Xiao J, Miao Q, Liu F, Yin QQ, Zhang CG, et al: A functional promoter polymorphism of IFITM3 is associated with susceptibility to pediatric tuberculosis in Han Chinese population. PLoS One 8: e67816, 2013.

17. Hashemi M, Sharifi-Mood B, Rasouli A, Amininia S, Naderi M and Taheri M: Macrophage migration inhibitory factor $-173 \mathrm{G} / \mathrm{C}$ polymorphism is associated with an increased risk of pulmonary tuberculosis in Zahedan, Southeast Iran. EXCLI J 14: 117-122, 2015.

18. Naderi M, Hashemi M,Taheri M,Pesarakli H,Eskandari-Nasab E and Bahari G: CD209 promoter -336 A/G (rs4804803) polymorphism is associated with susceptibility to pulmonary tuberculosis in Zahedan, southeast Iran. J Microbiol Immunol Infect 47: 171-175, 2014

19. Naderi M, Hashemi M, Pourmontaseri Z, Eskandari-Nasab E, Bahari $\mathrm{G}$ and Taheri M: TIRAP rs8177374 gene polymorphism increased the risk of pulmonary tuberculosis in Zahedan, southeast Iran. Asian Pac J Trop Med 7: 451-455, 2014.

20. Naderi M, Hashemi M, Hazire-Yazdi L, Taheri M, Moazeni-Roodi A, Eskandari-Nasab E and Bahari G: Association between toll-like receptor2 Arg677Trp and 597T/C gene polymorphisms and pulmonary tuberculosis in Zahedan, Southeast Iran. Braz J Infect Dis 15: 516-520, 2013.

21. Hashemi M, Eskandari-Nasab E, Moazeni-Roodi A, Naderi M, Sharifi-Mood B and Taheri M: Association of CTSZ rs34069356 and MC3R rs6127698 gene polymorphisms with pulmonary tuberculosis. Int J Tuberc Lung Dis 17: 1224-1228, 2013. 
22. Naderi M,Hashemi M and Amininia S: Association of TAPl and TAP2 Gene Polymorphisms with Susceptibility to Pulmonary Tuberculosis. Iran J Allergy Asthma Immunol 15: 62-68, 2016.

23. Bahari G, Hashemi M, Taheri M, Naderi M, Eskandari-Nasab E and Atabaki M: Association of IRGM polymorphisms and susceptibility to pulmonary tuberculosis in Zahedan, Southeast Iran. Sci World J 2012: 950801, 2012.

24. Hashemi M, Hanafi Bojd H, Eskandari Nasab E, Bahari A, Hashemzehi NA, Shafieipour S, Narouie B, Taheri M and Ghavami S: Association of Adiponectin rs1501299 and rs266729 Gene Polymorphisms With Nonalcoholic Fatty Liver Disease. Hepat Mon 13: e9527, 2013.
25. Everitt AR, Clare S, Pertel T, John SP, Wash RS, Smith SE, Chin CR, Feeley EM, Sims JS, Adams DJ, et al; MOSAIC Investigators: IFITM3 restricts the morbidity and mortality associated with influenza. Nature 484: 519-523, 2012.

26. Feeley EM, Sims JS, John SP, Chin CR, Pertel T, Chen LM, Gaiha GD, Ryan BJ, Donis RO, Elledge SJ, et al: IFITM3 inhibits influenza A virus infection by preventing cytosolic entry. PLoS Pathog 7: e1002337, 2011 